\title{
Pengaruh Perbedaan Metode Ekstraksi Metabolit Sekunder Streptomyces sp. GMR22 terhadap Toksisitas pada Sel BHK-21
}

\section{Effects of Extraction Methods of Secondary Metabolite Streptomyces sp. GMR22 towards BHK- 21 Cells Toxicity}

\author{
Diani Mentari $^{1^{*}}$, Mirtati Naima ${ }^{2}$, Riska Wulansari ${ }^{3}$, Jaka Widada $^{4}$, Tri Rini Nuringtyas ${ }^{3}$, Tri Wibawa ${ }^{5}$ \\ and Nastiti Wijayanti ${ }^{*}$ \\ ${ }^{1}$ Program Studi D-3 Teknologi Transfusi Darah STIKES Guna Bangsa Yogyakarta \\ ${ }^{2}$ Program Studi Biologi UIN Walisongo \\ ${ }^{3}$ Fakultas Biologi, Program Pascasarjana Universitas Gadjah Mada, Indonesia \\ ${ }^{4}$ Fakultas Pertanian, Universitas Gadjah Mada, Indonesia \\ ${ }^{5}$ Fakultas Kedokteran, Universitas Gadjah Mada, Indonesia \\ *E-mail: dianimentari@gmail.com and nastitiw@yahoo.com
}

\begin{abstract}
Abstrak
Potensi Streptomyces sebagai penghasil metabolit sekunder sudah cukup dikenal secara luas, dikarenakan Genus ini menghasilkan senyawa yang memiliki sifat multiple pleotropik action. Streptomyces. sp GMR22 merupakan isolat lokal yang diperoleh dari Hutan Wanagama I Yogyakarta, berpotensi untuk dikembangkan sebagai penghasil senyawa aktif karena diketahui memiliki gen PKS dan NRPS. Senyawa aktif hasil isolasi sangat dipengaruhi oleh berbagai macam faktor salah satunya adalah teknik ekstraksi. Perbedaan teknik ekstraksi suatu senyawa alam akan sangat berpengaruh terhadap kualitas metabolit sekunder yang dihasilkan. Tujuan penelitian ini adalah untuk membandingkan efek sitotoksisitas dari metabolit sekunder Streptomyces sp. GMR22 yang diperoleh dengan dua metode ekstraksi yang berbeda. Pada penelitian in ekstraksi bertingkat menggunakan metode corong pisah yaitu pertama diekstraksi dengan senyawa non polar (n-heksan) selanjutnya diektraksi kembali menggunakan senyawa semi polar (etil asetat). Pada penelitian sebelumnya metabolit sekunder diekstraksi dengan metode corong pisah hanya menggunakan senyawa etil asetat. Hal ini menyebabkan dengan penggunaan konsentrasi terendah pada uji antivial virus dengue (uji lanjutan) menyebabkan $100 \%$ kematian pada sel BHK-21. Hasil penelitian ini menunjukkan bahwa ekstraksi bertingkat menghasilkan nilai $\mathrm{CC}_{50}$ yang lebih rendah dibandingkan dengan penelitian sebelumnya yaitu 49,160 $\mu \mathrm{l} / \mathrm{ml}$ (hasil ekstraksi n-heksan) dan 284,56 $\mu \mathrm{l} / \mathrm{ml}$ (hasil ekstrak Etil Asetat) sedangkan ekstrak air $464,38 \mu \mathrm{l} / \mathrm{ml}$. Analisis senyawa dengan FTIR menunjukkan bahwa ketiga ekstrak yang dihasilkan memiliki pola spektrum yang berbeda terutama pada ektrak n-heksan dan ekstrak etil asetat. Adanya $\mathrm{CC}_{50}$ yang tidak terlalu tinggi diharapkan metabolit sekunder yang dihasilkan dapat digunakan untuk analisis lanjut seperti uji antivirus karena aman terhadap sel normal/sel host seperti sel BHK-21.
\end{abstract}

Kata Kunci: Streptomyces sp. GMR22, metabolit sekunder, BHK-21, FTIR, CC 50

\begin{abstract}
Streptomyces sp. GMR22 is local isolate from Wanagama 1 Forest in Yogyakarta. They have the potential to be developed to produce active compounds because have PKS and NRPS genes.The active compounds from isolation are strongly influenced by various factors, one of them is extraction techniques. Effect difference of extraction technique will be affected by the quality of secondary metabolites produced.The purpose of this study was to compare the cytotoxicity effects of secondary metabolites of Streptomyces sp. GMR22 which have extracted with different stages from previous studies. The extraction technique was carried out by multilevel separatory funnel extraction methods, which was first extracted using non-polar solvent (n-hexane) and then extracted using semi-polar solvent (ethyl acetate). This research is important because in previous studies (separatory funnel only extracted using ethyl acetate) with the use of the lowest concentration in the dengue virus antiviral test (further test) caused 100\% of deaths in BHK-21 cells.This study indicate that multilevel extraction result in lower $C C_{50}$ value than previous studies. There are 49.160 $\mu \mathrm{l} / \mathrm{ml}$ ( $\mathrm{n}$-hexane extract) and $284.56 \mu \mathrm{l} / \mathrm{ml}$ (ethyl acetate extract) while water extract is $464,38 \mu \mathrm{l} / \mathrm{ml}$. FTIR compound analysis show that the three extracts produced have different spectrum patterns, especially in the $n$-hexane and ethyl acetate extract. Value of $C_{50}$ is not too high, it is expected that the secondary metabolites
\end{abstract}


contained in the extracts can be used for further analysis such as antiviral testing because it is safe for normal host cells such as BHK-21 cells

Keywords: Streptomyces sp. GMR22, secondary metabolite, BHK-21, FTIR, $C_{50}$

\section{PENDAHULUAN}

Genus Streptomyces dikenal menghasilkan senyawa bioaktif dengan spektrum cukup luas sehingga dapat berfungsi sebagai antibiotik, antikanker, antiinflamasi, antifungi dan antivirus (Chaudhary et al., 2013). Oleh karena itu banyak peneliti melakukan skrining untuk mencari isolat baru yang berpotensi menghasilkan senyawa bioaktif sehingga memiliki manfaat untuk bidang farmasi (Gopinath dan Charya, 2013). Streptomyces sp. GMR22 merupakan isolat tanah dari Hutan Wanagama I Yogyakarta yang diperoleh dari bawah tegakan Kayu Putih (Nurjasmi, 2008). Isolat yang didapatkan ternyata memiliki spektrum metabolit sekunder cukup bervariasi. Hal ini dikarenakan Streptomyces sp. GMR22 memiliki gen PKS dan NRPS (Alimuddin, 2012). Gen PKS dan NRPS merupakan gen yang dapat memproduksi metabolit sekunder dengan variasi cukup besar, baik fungsi maupun struktur senyawanya (Riyanti et al., 2012).

Alimuddin (2011) melakukan uji aktivitas antifungi, hasil menunjukkan isolat Streptomyces sp. GMR22 memiliki efek antifungi terbaik dalam menghambat pertumbuhan Saccharomyces cerevisiae, Candida albicans, Aspergillus flavus dan Fusarium oxysporum. Streptomyces sp. GMR22 juga memiliki potensi sebagai antivirus Virus Dengue. Imaniar (2013) dan Praditya (2013) menyebutkan bahwa hasil uji WST-1 ekstrak air (bagian yang tidak larut dalam etil asetat) Streptomyces sp. GMR22 memiliki nilai $\mathrm{CC}_{50} 125 \mu \mathrm{g} / \mathrm{ml}$, namun dengan penggunaan konsentrasi $25 \mu \mathrm{g} / \mathrm{ml}$ sudah mampu menghambat pertumbuhan Virus Dengue serotipe 1 dan 2 sebesar $80 \%$.

Imaniar (2013) dan Praditya (2013) juga menggunakan ekstrak etil asetat Streptomyces sp. GMR22 untuk uji yang sama. Hasil nilai $\mathrm{CC}_{50}$ ekstrak etil asetat Streptomyces sp.
GMR22 adalah 20,59 $\mu \mathrm{g} / \mathrm{ml}$. Pada tahapan selanjutnya yaitu uji aktivitas antivirus dengan menggunakan beberapa variasi konsentrasi. Namun penggunaan konsentrasi terendah pada ekstrak etil asetat Streptomyces sp. GMR22 $(6,25 \mu \mathrm{g} / \mathrm{ml})$ menyebabkan kematian sel BHK-21 (sel host) sebesar $100 \%$.

Sel BHK-21 merupakan sel yang sering digunakan untuk propagasi berbagai macam jenis virus salah satunya virus dengue. Hal ini dikerenakan BHK-21 memiliki banyak reseptor yang sesuai virus dengue yaitu heparansulfat, glycoprotein dan DC-SIGN (Alen dan Schol, 2012). Tahapan terpenting pada uji antiviral adalah mencari senyawa yang tidak menyebabkan kematian sel host, sehingga perlu cara ekstraksi yang efektif untuk menghasilkan senyawa aman bagi sel BHK-21.

Efektifitas senyawa yang diperoleh dari biosintesis metabolit sekunder sangat dipengaruhi oleh teknik ekstraksi. Imaniar (2013) melakukan ektraksi metabolit sekunder Streptomyces sp. GMR22 dengan metode corong pisah menggunakan pelarut etil asetat menyebabkan senyawa yang dihasilkan terlalu toksik bagi sel BHK-21. Hal ini kemungkinan disebabkan karena pelarut etil asetat dapat melarutkan senyawa dengan spektrum yang cukup luas (larutan semipolar). Maka penelitian ini penting dilakukan untuk melihat perbedaan sitotoksisitas senyawa yang dihasilkan dari ekstraksi bertingkat yaitu pertama menggunakan pelarut n-heksan (non polar) yang kedua menggunakan pelarut etil asetat (semi polar).

\section{METODE PENELITIAN} Alat

Alat yang digunakan adalah alat-alat gelas, shaker, corong pisah (Pyrex), timbangan digital analitik (Chyo), waterbath 
(Memmert), sentrifuse (Beckman dan Hettich), Inkubator, Laminar Air Flow, ELISA reader (Benchmark), inkubator $\mathrm{CO}_{2}$ (Memmert), pH meter (Metrohm), Fourier Transform Infared/FTIR (Shimadzu).

\section{Bahan}

Streptomyces sp. GMR22 merupakan koleksi dari Dr. Ir. Jaka Widada, M.P dari Fakultas Pertanian UGM sedangkan kultur sel BHK-21 (adherent cell line dari Baby Hamster Kidney) berasal dari Lembaga Biologi Molekular Eijkman Jakarta.

Produksi metabolit sekunder Streptomyces Sp.GMR22

Produksi metabolit sekunder dilakukan dengan melakukan prekultivasi Streptomycess sp. GMR22 pada medium SNB (Starch Nitrat Broth) selama 5 hari pada suhu $\pm 28^{\circ} \mathrm{C}$, selanjutnya dikultivasi selama 15 hari pada media yang sama untuk menghasilkan metabolit sekunder. Hasil fermentasi kemudian disentrifuse dengan kecepatan 3000 rpm selama 35 menit untuk memisahkan pelet dan cairan supernatan. Cairan supernatan kemudian diekstraksi menggunakan corong pisah. Ekstraksi dilakukan secara bertingkat dengan pelarut n-heksan terlebih dahulu kemudian etil asetat Ekstrak yang didapat kemudian dipekatkan dengan waterbath. Adapun skema produksi metabolit sekunder Streptomyces sp. GMR22 dapat dilihat pada Gambar 1.

\section{Uji sitotoksik (WST-1 assay)}

Sel BHK-21 dengan kepadatan $2 \times 10^{3}$ $\mathrm{sel} /$ well (microplate 96 well) diinkubasi semalam pada $\mathrm{CO}_{2} 5 \%$ dengan suhu $37^{\circ} \mathrm{C}$. Media sel selanjutnya dibuang dan diberi serangkaian seri konsentrasi senyawa uji yang telah dilarutkan dalam media DMEM $10 \%$. Sel selanjutnya diinkubasi selama 24 jam pada inkubator $\mathrm{CO}_{2} 5 \%$ dengan suhu $37^{\circ} \mathrm{C}$. Pada jam ke-24, media dibuang dan ditambahkan media baru sebanyak $50 \mu 1$ serta $5 \mu 1$ larutan WST-1. Sel kemudian diinkubasi

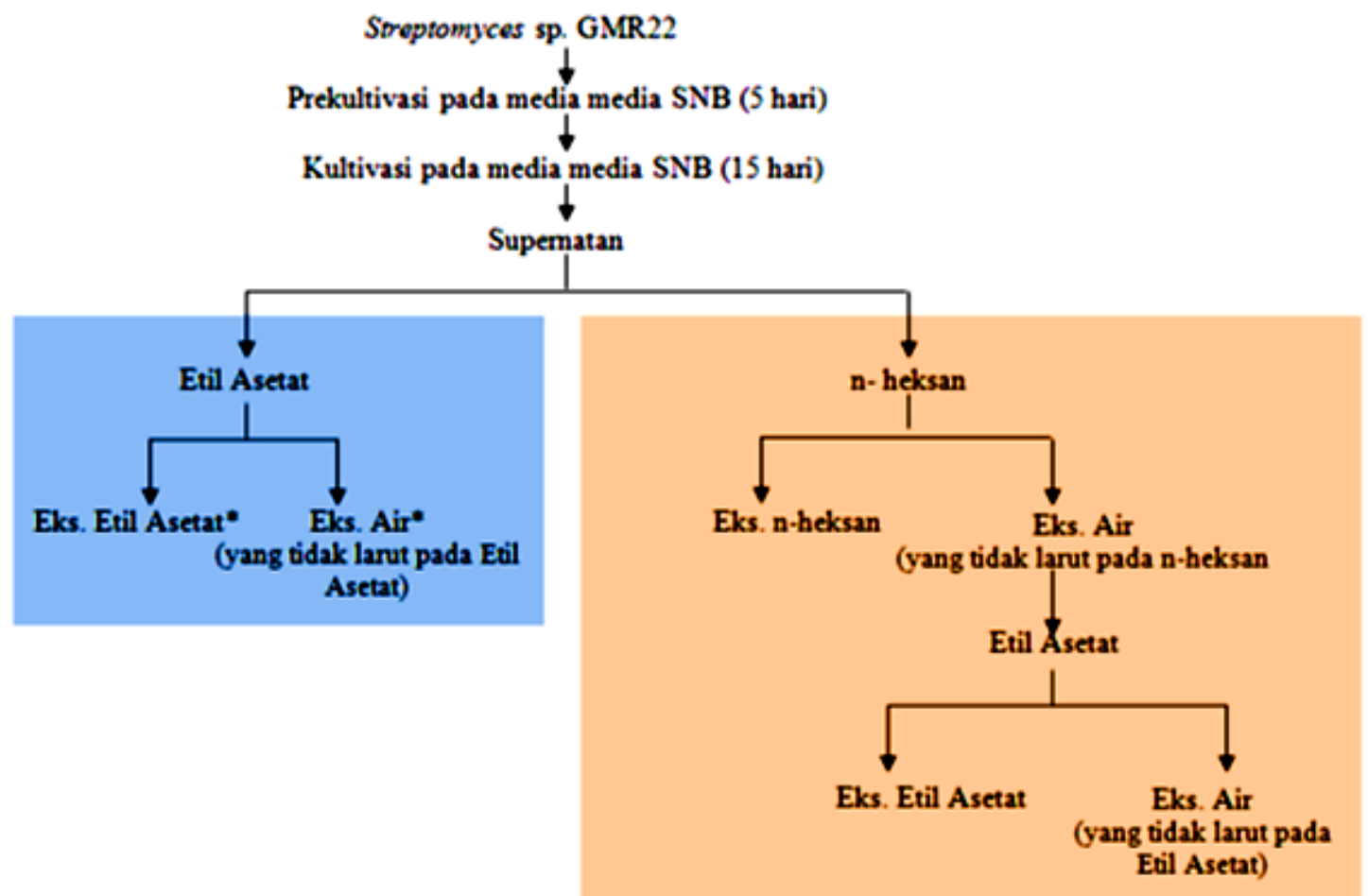

Gambar 1. Model ekstraksi dalam produksi metabolit sekunder Streptomyces sp. GMR22. Kotak biru menunjukkan ekstraksi yang dilakukan Imaniar (2013) dan kotak orange adalah ekstraksi yang dilakukan pada penelitian ini. 
Tabel 1. Hasil metabolit sekunder dari Streptomyces sp. GMR22

\begin{tabular}{lll}
\hline \multicolumn{1}{c}{ Jenis } & \multicolumn{1}{c}{ Warna } & \multicolumn{1}{c}{ Bentuk ekstrak } \\
\hline Supernatan & Coklat & Kental dan mengkristal \\
Ekstrak n-heksan & Kuning orange & Sedikit kental \\
Ekstrak Etil Asetat & Coklat kekuningan & Pasta \\
Ekstrak Air & Kehitaman & Mengkristal \\
\hline
\end{tabular}

kembali selama 4 jam dan dibaca absorbansinya pada jam ke $1 ; 2 ; 3 ; 4$ dengan ELISA reader (Benchmark) menggunakan panjang gelombang $450 \mathrm{~nm}$. Viabilitas sel dihitung persamaan 1 .

$$
\% \text { Sel Hidup }=\frac{\text { abs P-abs M }}{\text { abs K-abs M }} \times 100 \% \text {. }
$$

\section{Keterangan :}

abs $\mathrm{P}$ : absorbansi perlakuan

abs K : absorbansi kontrol sel

abs M : absorbansi kontrol media

\section{Analisis spektroskopi inframerah Fourier Transform Infared (FTIR)}

Sampel ekstrak/senyawa uji masingmasing ditimbang dengan menggunakan timbangan digital analitik sebanyak $0,2 \mathrm{mg}$ kemudian dianalisis spektroskopi inframerah (FTIR) (Shimadzu). Analisis dilakukan di Jurusan Kimia Fakultas MIPA UGM.

\section{Analisis Data}

Nilai $\mathrm{CC}_{50}$ ditentukan dengan analisis regresi linier pada program excell. Konsentrasi sampel (ekstrak) sebagai variabel bebas sedangkan persentase viabilitas sel sebagai variabel tergantung.

\section{HASIL DAN PEMBAHASAN}

Metabolit sekunder Streptomyces sp. GMR22 dihasilkan melalui proses fermentasi selama 15 hari pada medium SNB. Perubahan warna media (SNB) dari putih menjadi kuning orange setelah proses fermentasi dapat disebabkan adanya metabolit sekunder yang dihasilkan Streptomyces sp. GMR22 sehingga terdistribusi dalam media. Proses ektraksi berbeda dengan penelitian yang dilakukan Imaniar (2013), dimana supernatan diekstraksi secara bertingkat, pertama menggunakan pelarut non polar (n-heksan) kemudian dilanjutkan dengan pengojogan dengan etil asetat (semi polar). Senyawa dengan kepolaran menengah akan terekstrak dalam etil asetat, sedangkan bagian yang tidak larut pada pelarut n-heksan dan etil asetat disebut ekstrak air. Proses pencampuran serta pengojokan dilakukan sebanyak 3 kali. Ekstrak kemudian dipekatkan menggunakan waterbath. Ekstrak n-heksan pada suhu $68^{\circ} \mathrm{C}$, Ekstrak etil asetat pada suhu $76^{\circ} \mathrm{C}$ dan ekstrak air dan supernatan pada suhu $98^{\circ} \mathrm{C}$.

Adapun skema produksi metabolit sekunder Streptomyces sp. GMR22 dapat dilihat pada Gambar 1. Hasil ektraksi masing - masing senyawa memiliki perbedaan bentuk dan warna. Adapun hasil ekstraksi secara lengkap dapat dilihat pada Tabel 1. Hasil ekstraksi metabolit sekunder Streptomyces sp. GMR22 (Tabel 1.) memiliki bentuk dan warna yang berlaianan, maka untuk mengetahui kandungan senyawa dalam ekstrak dilakukan analisis spektroskopi Fourier Transform Infared (FTIR).

Fourier Transform Infared merupakan metode untuk mengamati interaksi molekul dengan radiasi elektromagnetik pada bilangan gelombang $10-13.000 \mathrm{~cm}^{-1}$. Gugus fungsi dapat diketahui melalui pita serapan dari interaksi tiap-tiap atom berdasarkan nilai panjang gelombang $\left(\mathrm{cm}^{-1}\right)$ yang spesifik (Harbone, 1984; Pavia et al., 2001). Analisis kualitatif dengan spektrometer IR bertujuan untuk menentukan gugus-gugus fungsional dalam sampel yang akan memberikan gambaran komponen senyawa hasil fermentasi metabolit sekunder Streptomyces sp. GMR22 dengan berbagai pelarut. Uji 
FTIR juga dilakukan pada supernatan Streptomyces sp. GMR22 (hasil metabolit sekunder yang belum diekstrak) dan media SNB (media yang digunakan untuk produksi metabolit sekunder). Hasil analisis FTIR memperlihatkan bahwa ternyata ekstrak air memiliki kandungan senyawa yang mirip dengan supernatan Streptomyces sp. GMR22 dan media SNB, ini terlihat dari pola spektrum yang hampir sama (Gambar 2). Hal ini memperlihatkan bahwa pada ekstrak air Streptomyces sp. GMR22 masih banyak mengandung komponen media SNB. Adanya rentangan gugus - $\mathrm{OH}$ dengan intensitas yang cukup kuat dengan puncak yang agak lebar pada daerah $3402,43 \mathrm{~cm}^{-1}$ (pada supernatan), $3456,44 \mathrm{~cm}^{-1}$ (pada air), 3448,72 $\mathrm{cm}^{-1}$ (pada etil asetat) dan $3425,58 \mathrm{~cm}^{-1}$ (pada media $\mathrm{SNB}$ ). Gugus -OH ini kemungkinan merupakan gugus hidroksil dari alkohol dan fenol (Jindo et al., 2014) yang diduga berasal dari karbohidrat, atau dari molekul air yang teradsorpsi (Zhuetal, 2012; Kennedy, 2005) oleh sampel. Pada ekstrak etil asetat terdapat peak yang cukup tinggi pada rentangan $1.728,22 \mathrm{~cm}^{-1}$ yang menunjukkan gugus karbonil dan rentangan $1.126,43 \mathrm{~cm}^{-1}$ yang

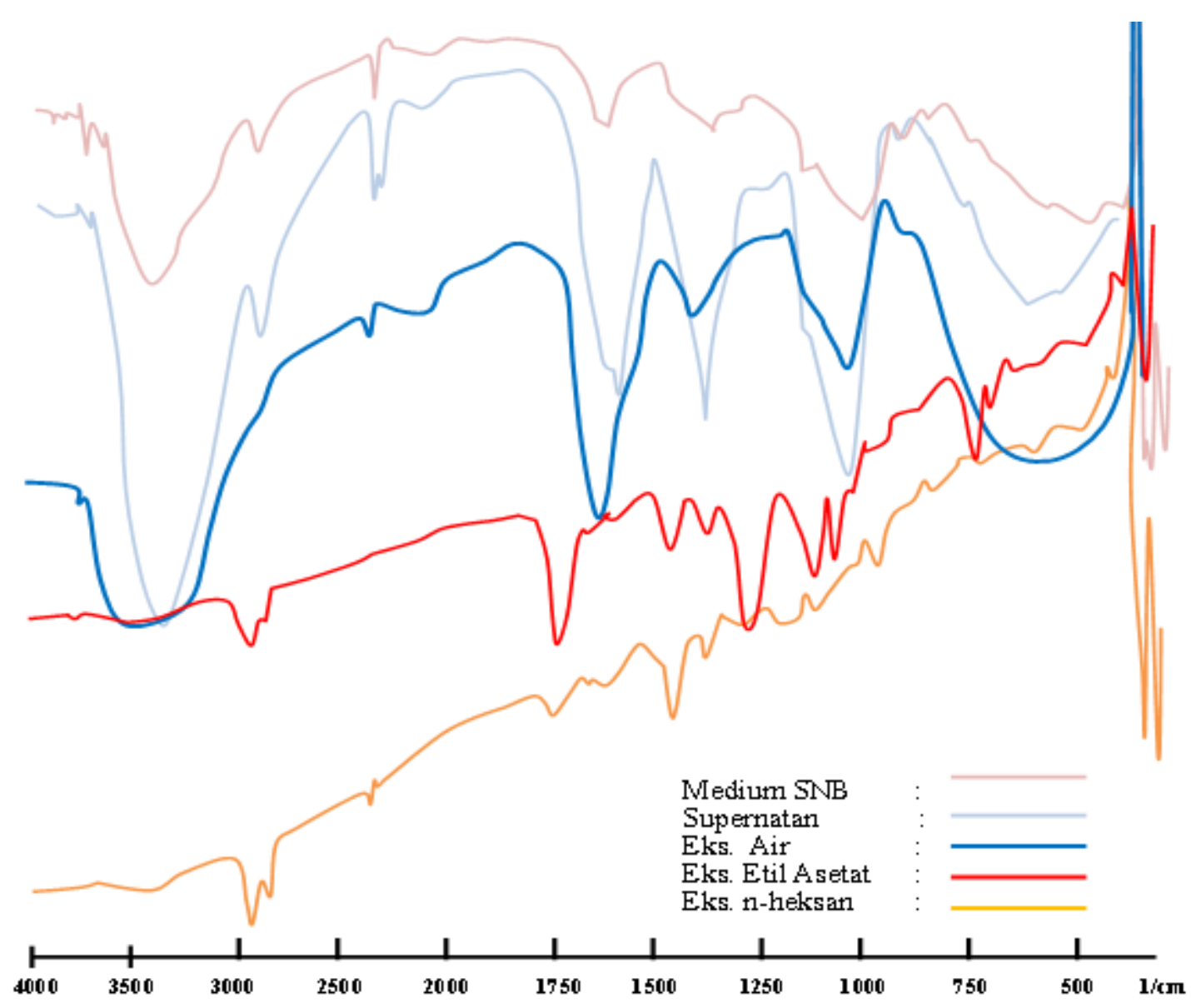

Gambar 2. Hasil analisis FTIR medium SNB (garis coklat muda), supernatan, (garis biru muda) ekstrak air (garis biru), ekstrak etil asetat (garis merah) dan ekstrak n-heksan (garis orange) dari Streptomyces sp GMR22. Pola spektrum menunjukkan adanya perbedaan gugus fungsi. 
menunjukkan gugus Sulfon (Perumal et al., 2015, Kosela, 2013).

Pada Gambar 2 nampak terlihat bahwa ekstrak n-heksan dan etil asetat menghasilkan pola spektrum yang berbeda. Hasil analisis pola serapan FTIR yang didapat dari ekstrak n-heksan Streptomyces sp. GMR22 menunjukkan berbagai macam ikatan. Pada daerah serapan $3448,72 \mathrm{~cm}^{-1}$ menunjukkan adanya gugus hidroksil (-OH). Hal ini diperkuat dengan adanya pita serapan pada bilangan gelombang $1743,65 \mathrm{~cm}^{-1}$ adalah ciri khas adanya $\mathrm{C}=\mathrm{O}$ suatu keton/ester (Rante, 2015). Serta serapan pada $3070,68 \mathrm{~cm}^{-1}$ yang menunjukkan cincin aromatik. Hossain et al. (2006) mengungkapkan bahwa penggunaan FTIR dapat mendeteksi senyawa flavanoid melalui gugus-gugus fungsi yang muncul seperti hidroksil $(\mathrm{OH})$, karbonil $(\mathrm{C}=\mathrm{O})$ serta senyawa aromatik. Adapun spektra FTIR

Tabel 2. Interpretasi jenis ikatan dan gugus fungsi dari metabolit sekunder Streptomyces sp. GMR22 berdasarkan daerah serapan FTIR

\begin{tabular}{|c|c|c|c|c|c|}
\hline \multicolumn{3}{|c|}{$\begin{array}{c}\text { Bilangan gelombang pada } \\
\text { masing-masing Ekstrak }\left(\mathrm{cm}^{-1}\right)\end{array}$} & \multicolumn{3}{|c|}{ Interpretasi Spektra umum $\left(\mathrm{cm}^{-1}\right)$} \\
\hline n-heksan & $\begin{array}{c}\text { Etil } \\
\text { Asetat }\end{array}$ & Air & Anonim (2016) & Socrates (2011) & Kosela (2013) \\
\hline 3448,72 & 3417,86 & 3456,44 & $\begin{array}{l}\text { 3200-3500 (Alkohol, } \\
\text { fenol) }\end{array}$ & & \\
\hline 3070,68 & 3070,68 & - & 3000-3100 (Aromatik) & & \\
\hline 2924,09 & 2931,8 & - & 2850-3000 (Alkana) & & \\
\hline 2854,65 & 2862,36 & - & 2850-3000 (Alkana) & & \\
\hline 1743,65 & $1.735,93$ & - & $\begin{array}{l}1735-1750 \text { (Ester, } \\
\text { saturated aliphatic) }\end{array}$ & & $\begin{array}{c}1.720- \\
1.740(\text { Aldehid) } \\
1.715-1.740(\text { Ester }) \\
1.725-1.750(\delta- \\
\text { lakton) }\end{array}$ \\
\hline- & $1.728,22$ & - & & & \\
\hline 1627,92 & - & 1635,64 & $1580-1650\left(1^{\circ} \mathrm{amin}\right)$ & $\begin{array}{c}\sim 1650 \text { (Amide I } \\
\text { band, dipengaruhi } \\
\text { oleh adanya ikatan } \\
\text { hidrogen) }\end{array}$ & \\
\hline 1458,18 & 1465,9 & $\begin{array}{l}1342,46 \\
1141,89\end{array}$ & 1450-1470 (Alkana) & $\begin{array}{l}\text { 1450-1750 (COO- } \\
\text { vibrasi asimetrik) }\end{array}$ & \\
\hline 1296,16 & $1.280,73$ & - & $\begin{array}{c}\text { 1250-1335 (Aromatic } \\
\text { amin) }\end{array}$ & & \\
\hline 1257,59 & - & - & $\begin{array}{c}\text { 1250-1335 (Aromatic } \\
\text { amin) }\end{array}$ & & \\
\hline 1111,00 & $1.126,43$ & $\begin{array}{l}1033,85 \\
1234,44\end{array}$ & $\begin{array}{c}\text { 1020-1250 (Alifatil } \\
\text { amin) }\end{array}$ & $\begin{array}{l}\text { PO2- vibrasi } \\
\text { asimetris }\end{array}$ & $\begin{array}{l}1.100-1.150 \\
\text { (Sulfon) }\end{array}$ \\
\hline- & $1.072,42$ & - & & & $\begin{array}{l}\text { Alkil fluoride } \\
(1.000-1.400)\end{array}$ \\
\hline 972,12 & - & - & 650-1000 (Alkena) & & \\
\hline 833,25 & 624,94 & & 550-850 (Alkil halida) & & \\
\hline- & 740,67 & - & & & $\begin{array}{c}500-800 \\
\text { (Alkilklorida/bromi } \\
\text { de/iodide) }\end{array}$ \\
\hline 725,23 & - & - & 720-725 (Alkana) & & \\
\hline 671,23 & 624,94 & 601,79 & $\begin{array}{l}\text { 515-690 (Alkil } \\
\text { Halida) }\end{array}$ & & $\begin{array}{c}500-800 \\
\text { (Alkilklorida/bromi } \\
\text { de/iodide) }\end{array}$ \\
\hline 586,36 & - & - & $\begin{array}{c}\text { 515-690 (Alkil } \\
\text { Halida) } \\
\end{array}$ & & \\
\hline
\end{tabular}


ekstrak n-heksan Streptomyces sp. GMR22 memperlihatkan beberapa gugus fungsi yang ditunjukkan oleh beberapa bilangan gelombang dan interpretasi jenis ikatan dapat dilihat pada Tabel 2.

Pita serapan kuat antara $3000-2800 \mathrm{~cm}^{-1}$ yaitu pada 2924,09 dan 2854,65 $\mathrm{cm}^{-1}$ menunjukkan adanya ikatan $\mathrm{C}-\mathrm{H}$ alifatik yang berupa metil $\left(\mathrm{CH}_{3}\right)$ dan metilena $\left(\mathrm{CH}_{2}\right)$. Hal ini diperkuat dengan adanya vibrasi bengkokan C-H pada daerah serapan 1458,18 $\mathrm{cm}^{-1}$. Keberadaan gugus piridin ditunjukkan pada serapan $1627,92 \mathrm{~cm}^{-1}$ yang diperkuat oleh serapan pada $1296,16 \mathrm{~cm}^{-1}$ yaitu serapan untuk amina heterosiklik. Data spektrum inframerah pada Tabel 2 menginterpretasikan bahwa ekstrak n-heksan Streptomyces $s p$ GMR22 mengandung gugus amin $(\mathrm{NH})$, fenolik, cincin aromatik dan ester/keton $(\mathrm{C}=\mathrm{O})$. Hal ini sesuai dengan hasil KLT ekstrak n-heksan Streptomyces sp. GMR22
(Mentari, 2016 Data tidak dipublikasikan). Hasil spektra FTIR beberapa senyawa dalam ekstrak Streptomyces sp. GMR22 seperti fenol, flavanoid dan terpenoid serta terdapat gugus amin dan cincin aromatis. Senyawa tersebut belum diketahui efek toksisitasnya, maka untuk mengetahuinya, dilakukan uji sitotoksik terhadap sel BHK-21. Uji sitotoksik juga dilakukan pada medium SNB dan supernatan Streptomyces sp. GMR22 yang digunakan sebagai pembanding

Viabilitas sel BHK-21 dengan pemberian beberapa hasil ektraksi Metabolit sekunder Streptomyces sp. GMR22 dapat dilihat pada Tabel 3. Uji Sitotoksik merupakan tahap awal untuk melihat konsentrasi maksimum ekstrak/senyawa yang dapat diberikan pada sel normal ketika digunakan untuk uji antivirus (Marbawati et al., 2014). Dalam penelitian ini uji sitotoksik dilakukan dengan metode WST-1. Uji WST-1 menggunakan

Tabel 3. Peresentase viabilitas sel BHK-21 setelah pemberian ekstrak dari metabolit sekunder Streptomyces sp. GMR2

\begin{tabular}{ccc}
\hline Perlakuan sampel & $\begin{array}{c}\text { Konsentrasi } \\
(\mu \mathrm{g} / \mathrm{ml})\end{array}$ & $\begin{array}{c}\text { Persentase Sel } \\
\text { Hidup }(\%)\end{array}$ \\
\hline Supernatan & 600 & 50,49 \\
& 300 & 64,3 \\
& 150 & 73,31 \\
& 75 & 81,82 \\
\hline n-heksan & 37,5 & 108,74 \\
& 50 & 49,23 \\
Etil asetat & 40 & 58,43 \\
& 30 & 73,13 \\
& 20 & 80,07 \\
\hline Air & 500 & 21,15 \\
& 250 & 49,34 \\
& 125 & 93,05 \\
& 62,5 & 96,21 \\
& 31,25 & 55,58 \\
\hline & 160 & 79,90 \\
& 80 & 85,00 \\
& 40 & 89,60 \\
& 20 & 96,60 \\
\hline
\end{tabular}




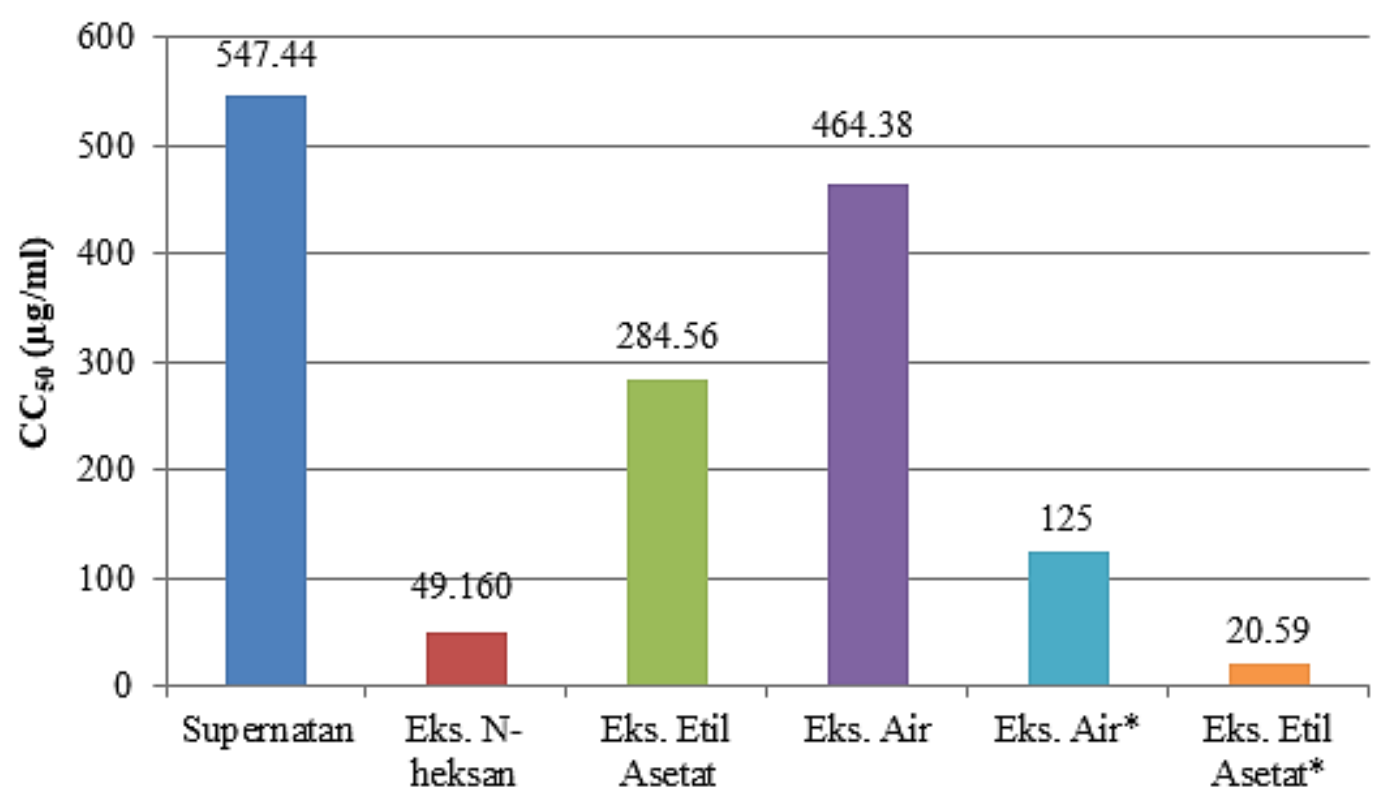

Ekstrak Streptomyces sp. GMR22

Gambar 3. Nilai CC50 dari beberapa ekstrak Streptomyces sp. GMR22 pada sel BHK-21. Tanda bintang (*), menunjukkan hasil uji sitotoksik yang dilakukan oleh Imaniar (2013).

garam tetrazolium, garam ini akan bereaksi ketika ada aktivitas mitokondria sehingga terbentuk formazan yang dapat diukur absorbansinya (Berridge et al., 2005). Pada uji WST-1 baik supernatan maupun ekstrak nheksan dan etil asetat Streptomyces sp. GMR22 dilarutkan dalam pelarut DMSO $0,5 \%$. Hasil uji sitotoksik memperlihatkan bahwa pemberian tiap-tiap ekstrak metabolit sekunder Streptomyces sp. GMR22 memberikan efek yang berbeda terhadap viabilitas sel BHK-21. Namun secara umum semua sampel menunjukkan pola dose dependent yaitu semakin tinggi konsentrasi sampel yang diberikan akan menurunkan viabilitas dari sel BHK-21.

Hasil uji sitotoksik kemudian dibuat persamaan regresi antara persentase jumlah sel hidup dengan konsentrasi supernatan untuk mengestimasi nilai $\mathrm{CC}_{50}$ (Gambar 3). Hasil uji sitotoksik memperlihatkan bahwa seluruh ekstrak Streptomyces sp. GMR22 memiliki kemampuan sitotoksik pada sel BHK-21 dimana nilai $\mathrm{CC}_{50}$ tertinggi adalah
Supernatan yaitu 547,44 $\mu \mathrm{l} / \mathrm{ml}$ dan yang terendah adalah ekstrak n-heksan yaitu sebesar 49,160 $\mu \mathrm{l} / \mathrm{ml}$. Nilai $\mathrm{CC}_{50}$ ekstrak etil asetat sangat berbeda dengan hasil penelitian Imaniar (2013). Supernatan yang langsung diekstrak menggunakan etil asetat memiliki nilai $\mathrm{CC}_{50}$ yaitu $20,59 \mu \mathrm{l} / \mathrm{ml}$. Pada penelitian ini, hasil fermentasi Streptomyces sp. GMR22 diekstraksi cair-cair dengan n-heksan terlebih dahulu kemudian dilanjutkan ekstraksi caircair dengan eti asetat, hasilnya nilai $\mathrm{CC}_{50}$ ekstrak etil asetat sebesar 284,56 $\mu \mathrm{l} / \mathrm{ml}$. Begitupula pada ekstrak air pada penelitian sebelumnya adalah $125 \mu \mathrm{l} / \mathrm{ml}$ sedangkan pada penelitian ini, nilainya lebih rendah yaitu $464,38 \mu \mathrm{l} / \mathrm{ml}$. Perbedaan metode ekstraksi pada penelitian ini menyebabkan senyawa akan terdistribusi lebih merata pada ketiga pelarut tersebut (n-heksan, etil asetat dan air). Berbeda dengan metode ekstraksi sebelumnya dimana hasil fermentasi langsung diekstrak menggunakan senyawa etil asetat saja. Hal ini menyebabkan senyawa tidak dapat terlarut pada pelarut etil asetat akan tersisa pada 
ekstrak air. Akumulasi senyawa yang terdapat pada ekstrak air akan menyebabkan nilai toksisitas yang cukup tinggi $(120 \mu \mathrm{l} / \mathrm{ml})$. Selain itu, adanya perbedaan toksisitas tiap ekstrak dapat disebabkan oleh kemampuan masing-masing senyawa untuk masuk melewati membran sel. Membran sel yang terdiri atas dwi fosfolipida akan bersifat hidrofobik dan selektif permeabel (Alberts $e t$ al., 2008). Hal inilah yang mengakibatkan senyawa larut dalam air seperti supernatan maupun ekstrak air akan lebih sukar masuk ke dalam membran sel sehingga toksisitas senyawa juga lebih rendah.

\section{KESIMPULAN}

Hasil penelitian ini menunjukkan bahwa ekstraksi bertingkat metabolit sekunder Streptomyces sp. GMR22 menggunakan pelarut $\mathrm{n}$-heksan dan etil asetat menghasilkan senyawa dengan nilai toskisitas lebih rendah dibandingkan penelitian sebelumnya (langsung diekstrak menggunakan senyawa semi polar/etil asetat.

\section{UCAPAN TERIMAKASIH}

Penelitian ini didanai oleh Hibah PUPT UGM.

\section{Daftar Pustaka}

Alberts, B., Johnson A., Lewis, J., Raff, M., Roberts, K. dan Walte, P, 2008, Molecular Biology of The Cell. USA : Gerland Science Fifth Edition.

Alen, M. M. F., dan Schols D, 2012, Review Article: Dengue Virus Entry as Target for Antiviral Therapy, Journal of Tropical Medicine. Vol 2012. pp. 1-13

Alimuddin, Widada, J, Asmara, W., dan Mustofa, 2011, Antifungal Production of a Strain of Actinomycetes Spp Isolated from the Rhizosphere of Cajuput Plant: Selection and Detection of Exhibiting Activity Against Tested Fungi, Indonesian Journal of Biotechnology, 16(1), pp. 1-10.

Alimuddin, 2012, Actinomycetes Penghasil Antifungi Rizosfer Tegakan Kayu Putih Hutan Wanagama I Yogyakarta : Isolasi, Optimasi dan Karakterisasi Actinomycetes serta Isolasi Senyawa Antifungi, (Disertasi, Universitas Gadjah Mada Yogyakarta, Program Studi Bioteknologi Sekolah Pascasarjana).

Anonim, 2016, Table of Characteristic IR Absorptions. University of Colorado at Boulder, Department of Chemistry and Biochemistry. http://orgchem.colorado.edu/Spectroscopy/specttutor/irchart.pdf.

Berridge, M.V., Herst, P.M., Tan, A,S., 2005, Tetrazolium Dyes as Tools in Cell Biology: New Insights into their Cellular Reduction, Biotechnology Annual Review, Vol 11, pp. 127 152.

Chaudhary, H.S., Soni, B., Shrivastava, A.R., Shrivastava, S, 2013, Diversity and Versatility of Actinomycetes and its Role in Antibiotic Production, Journal of Applied Pharmaceutical Science, 3 : S83-S94. 
Gopinath, B.V., dan Charya, M.A.S., 2013, Characterization of Antibacterial Compounds Produced by The Actinomycetes using NMR Spectral Analysis, International Journal of Pharma Sciences and Research (IJPSR), 4(2), pp. 25-35.

Harborne, J.B., 1983, Metode Fitokimia :Penuntun Cara Modern Menganalisis Tumbuhan, ITB Prees : Bandung.

Imaniar N.I., 2014, Marine and Soil Actinomycetes Secondary Metabolite Antivirus Activity Against Dengue Serotype-1 Virus, (Thesis, Universitas Gadjah Mada Yogyakarta Program Studi Bioteknologi).

Jindo, K, Mizumoto, H., Sawada, Y., Sanchez-Monedero, M. A danSonoki., 2014, Physical and Chemical Characterizations of Biochars Derived from Different Agricultural Residues, Biogeosciences Discuss, 11: 11727-11746.

Kennedy, L. J., Vijaya, J. J., Sekaran, G. 2005, Electrical conductivity study of porous carboncomposite derived from rice husk, Mater. Chem. Phys, 91, pp. 471-476.

Marbawati D, Sardjiman, Yulianti, R., 2014, Efektivitas Pentagamavunon-0 (PGV-0) padaFaseAwalInfeksi Virus Dengue-2, Aspirator, 6 (2), pp. 43-48.

Nurjasmi, R., Widada J., Ngadiman, N, 2009, Diversity of Actinomycetes at Several Forest Types in Wanagama I Yogyakarta and Their Potency as a Producer of Antifungal Compound, Indonesian Journal of Biotechnology, 14(2), pp. 1196-1205.

Pavia, D.L., Lampman, G.M., Kriz, G.S., dan Vyvyan, J.R., 2001, Introduction to Spectroscopy. Fourth Edition. Departemant of Chemistry, Western Washington University Bellingham, Washington

Praditya, D.F. 2014. Potential Ethyl Asetat Extracts Of Secondary Metabolit Aktinomisetes to Againt Virus Dengue Serotype-2 (DENV-2), (Thesis, Universitas Gadjah Mada Yogyakarta Program Studi Bioteknologi).

Rante H, 2012, Isolasi dan Karakterisasi Actinomycetesasosiasi Spons Penghasil Antibiotik Koleksi Pulau Barrang Lompo Makassar, (Disertasi, Universitas Gadjah Mada. Yogyakarta, Ilmu Farmasi).

Riyanti, Aziz S., Sabdono A., Radjasa, O.K., 2012, Deteksi Gen Nrps Aktinomisetes Simbion Rumput Laut Dan Karang Lunak, Prosiding Seminar Nasional "Pengembangan Sumber Daya Pedesaan dan Kearifan Lokal Berkelanjutan II" Purwokerto, 27-28 Nopember 2012, pp. 177-182.

Socrates, G, 2007, Infrared and Raman Characteristic Group Freuencies Tables and Charts Third Edition. John Wiley and Sons, Ltd: United States.

Zhu, K., Fu, H., Zhan, J., Lv, X., Tang, J., Xu, X., 2012, Studies on removal of NH4-N from aqueous solution by using the activated carbons derived from rice husk, Biomass Bioenergy, 43, pp.18-25. 